Bolm Inst. oceanogr., S Paulo, 31(2):85-94, 1982

\title{
STANDING-STOCK AND POTENTIAL OF PHYTOPLANKTON PRODUCTION IN THE BAY OF SANTOS, BRAZIL
}

\author{
Sônia Maria Flores GIANESELLA-GALVÃo \\ Instituto de Biociências da Universidade de São Paulo
}

\section{Synopsis}

Phytoplankton primary production and the maximum photosynthetic index $\left(P^{b} m\right)$ from the region of Bay of Santos were measured every two months during 1976 by simulated incubations using i $4 \mathrm{C}$ method and incandescent lamps (737 $\left.\mu \mathrm{E} \cdot \mathrm{m}^{-2} \cdot \mathrm{s}^{-1} \cong 40 \mathrm{klux}\right)$. The results obtained for production rates (maximim of $204.6 \mathrm{mgC} \cdot \mathrm{m}^{-3} \cdot \mathrm{hr}^{-1}$ in winter and $488.3 \mathrm{mgC} \mathrm{m} \mathrm{m}^{-3} \cdot \mathrm{hr}^{-1}$ in summer) are among the highest recorded for tropical marine environments. A high capability of light adaptation under high temperatures was also verified. The photosynthetic indexes obtained were also very high and seems to be due to the high nutrient level of the region. The eutrophic state is supported by the high nutrient and chlorophyll-a concentrations and by the phytoplankton cells number.

\section{Introduction}

The region of the Estuary and Bay of Santos ( $\left.24^{\circ} 00^{\prime} \mathrm{S} ; 46^{\circ} 26^{\prime} \mathrm{W}\right)$, Brazil (Fig. 1) receives a great contribution of domestic and industrial wastes, besides those arising from the activities of the Port of Santos. These inputs into the area, an environment with natural eutrophic features, not only increase the speed of the eutrophication process but also contribute significantly to the pollution of the environment.

The study area has been subjected to an intense research program with the objective of providing a comprehensive ecosystem study and the necessary data for further studies and for the management of the area. A cooperative program between the Companhia de Tecnologia de Saneamento Ambiental (CETESB) and the Instituto Oceanográfico da Universidade de São Paulo was established. By this cooperative program, the hidrologica1, chemical and biological surveys of the Estuary and Bay were conducted from 1974 through 1977. The present work is based on data collected during 1976, under the mentioned program.

The study of the phytoplankton primary production was undertaken in the present work because this parameter may be a reasonable indicator of eutrophication of the environment and of its progress with time.

Studies on primary production in bays and estuarine regions have been carried out in Brazil by many authors (GarciaOcchipinti et al., 1961; Teixeira, 1969, 1980; Teixeira et al., 1969; Tundisi, 1969; Tundisi et al., 1973) but no one of them, were concerned to polluted environments.

Material and methods

Samples were taken every two months from February through December, 1976, only at surface and at three stations shown in Figure 1.

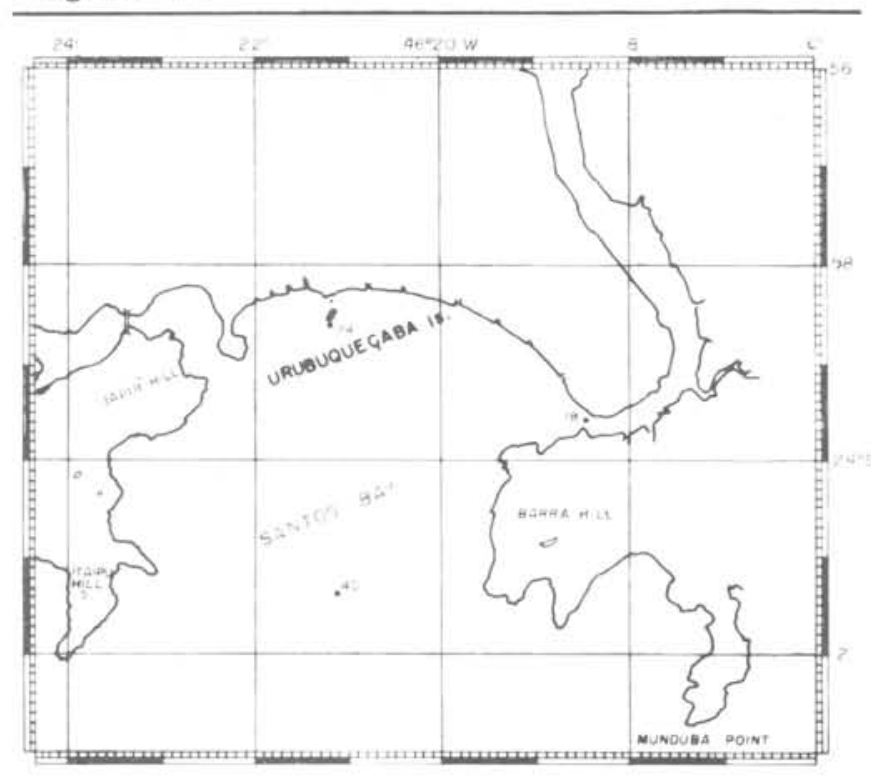

Fig. 1. Map of the Bay of Santos with the location of the Stations.

Publ. no 545 do Inst. oceanogr. da Usp. 
Hydrological and chemical analyses salinity, dissolved oxygen, $\mathrm{pH}$, nutrients (nitrite, nitrate, ammonia, orthophosphate) and $\mathrm{Hg}$ - were made by CETESB according to A.P.H.A. (1971).

Since the dissolved inorganic carbon in the samples could not be determined, the standard value of $90 \mathrm{mgCO}_{2} \mathrm{I}^{-1}$ (Gargas, 1975) was assumed for the present work.

Sub-samples for phytoplankton counts were fixed with formol solution to a final concentration of $5 \%$. The counts were determined in sedimentation chambers using an inverted microscope, according to Utermöh1 (1958).

For the spectrophometric chlorophy11-a analysis, a volume of $0.25 \ell$ seawater was filtered through $0.45 \mu \mathrm{m}$ Millipore HA filters. Pigments were extracted in $90 \%$ acetone. Details of the methodology and equations used are described in Strickland \& Parsons (1968).

Primary production was measured according to the ${ }^{14} \mathrm{C}$ method (SteemannNielsen, 1952). Samples were inoculated with tracer ( $16 \mu \mathrm{Ci}$ in $750 \mathrm{ml}$ of seawater). and transferred to $80 \mathrm{ml}$ glass bottles. They were incubated for three hours in an incubator with incandescent light $\left(737 \mu \mathrm{E} \cdot \mathrm{cm}^{-2} \cdot \mathrm{s}^{-1}\right.$ or $\left.40 \mathrm{klux}\right)$ under different light intensities, obtained by means of neutral filters: 2.0, 5.6, 25.6, $56.5 \%$. A $150.0 \%$ value was obtained using a mirror behind the bottle. Two (2) light bottles and one (1) black were used for each light level.

After incubation, $25 \mathrm{ml}$ sub-samples from each bottle were filtered through $0.45 \mu \mathrm{m}$ Millipore filters.

The filters were submitted to $\mathrm{HCl}$ fumes to eliminate the inorganic carbon. Filter activities were determined by liquid scintillation method according to Ward \& Nakanishi (1971). Calibration was performed by means of automatic external standardization. The fluor was a Bray solution (Bray, 1960) alkalized at $10 \%$ with hyamin hidroxide $10-\mathrm{X}$ (Packard).

The total light energy was measured with a LIQUOR quantameter, equipped with an underwater sensor for incident photon flux density (LI-192S).

\section{Results}

Table 1 shows the results of hydrological and chemical data. The D.0. saturation percentages were always high $(>70.7 \%)$ several times showing oversaturation. Salinity was between 28.38 and $33.5 \%$ at Stations 40 and 24 but at Station 18 it was between 18.48 and $32.41 \%$. Temperature was high during all the sampling period (between 19.86 and $27.51^{\circ} \mathrm{C}$ ). $\mathrm{pH}$ varied little but a high $\mathrm{pH}$ value (8.7) was observed in December, at Station 24 , concomitantly with a high value of dissolved oxygen.

Both phosphate and inorganic nitrogen showed a gradient increasing toward the estuary entrance. Mean values for Stations 40,24 and 18 were respectively $1.44,1.98$ and $4.22 \mu \mathrm{g} \mathrm{P}-\mathrm{PO}_{4} \cdot 1^{-1}$ and $10.84,15.97$ and $21.53 \mu \mathrm{gN}-\left(\mathrm{NO}_{3}+\mathrm{NO}_{2}+\mathrm{NH}_{3}\right)$. $1^{-1}$. The $\mathrm{N}: \mathrm{P}$ ratio never exceeded 10 .

$\mathrm{Hg}$ concentrations were high occasionally. During winter they were ten times higher than the maximum level found by Fitzgerald \& Lions (1973) in seawater $\left(0.003\right.$ to $\left.0.364 \mu \mathrm{g} \cdot 1^{-1}\right)$. The

\section{Table I - Hydrological and chemical parameters}

\begin{tabular}{|c|c|c|c|c|c|c|}
\hline Parameter & $\begin{array}{c}\text { Station } \\
\text { feb }\end{array}$ & $\begin{array}{l}40 \text { llocal } \\
\text { Apr }\end{array}$ & $\begin{array}{l}\text { depth: } \\
\text { Jun }\end{array}$ & $\begin{array}{l}\text { 12m) } \\
\text { Aug }\end{array}$ & oct & Dec \\
\hline Tide & high & high & low & low & high & high \\
\hline Sampling time & $14: 45$ & $17: 45$ & $17: 30$ & $16: 20$ & $13: 45$ & $14: 45$ \\
\hline Light extinction coef. & 1.20 & 0.90 & 0.90 & 1.06 & 0.85 & 1.20 \\
\hline Woter tesperature $(" c)$ & 26.20 & 26.30 & 21.20 & 21.20 & 21.33 & 25.05 \\
\hline solinity $(\% / . .0)$ & 32.33 & 30.83 & 29.68 & 30.90 & 33.03 & 33.50 \\
\hline D.0. saturation (z) & 90.8 & 82.9 & 107.7 & 127.3 & 102.9 & 148.0 \\
\hline pH & 8.0 & 8.2 & R.1 & 8.0 & 8.1 & 8.3 \\
\hline$N-N H,\left(u g \circ t \cdot 1^{-1}\right)$ & 0.00 & 0.00 & 0.00 & 0.70 & 0,00 & 0.00 \\
\hline $\mathrm{N}-\mathrm{NO}$, (Hg $A, \cdot \mathrm{I}^{-1}$ ) & 0.70 & 1.42 & 2.14 & 2.85 & 0.00 & 0.00 \\
\hline N-NO, (ug at: $-1^{-1}$ ) & 6.43 & 13.57 & 12.14 & 12.85 & 0.70 & 0.70 \\
\hline IN (vg $\left.* t, 1^{-1}\right)$ & 7.13 & 14.99 & 14.28 & 16.40 & 0.70 & 0.70 \\
\hline$\rightarrow \rightarrow 0$ (ug at $1^{-1}$ ) & 0.96 & 1.54 & 3.61 & 2.13 & 0.19 & 0.19 \\
\hline$N-N O,: P-P O$ & 6.7 & 8.8 & 3.4 & 6.0 & 3.7 & 3.7 \\
\hline \multirow[t]{2}{*}{$\mathrm{Hg}\left(\right.$ ug. $\left.1^{-1}\right)$} & 0.00 & 0.00 & 2.05 & 1.50 & 0.07 & 0.00 \\
\hline & Station 2 & 24 flocal & depth: 6 & 6m) & & \\
\hline Tide & high & low & $\cdot$ & high & high & 10u \\
\hline sampling time & 16.45 & 14.25 & $\cdot$ & 14.45 & 15.55 & 15.00 \\
\hline Liaht extinction coef. & 1.50 & 1.20 & $\cdot$ & 1.70 & 2.10 & 1.20 \\
\hline Water temperature $\left({ }^{\circ} \mathrm{C}\right)$ & 26.70 & 26.20 & - & 19.86 & 21.37 & 27.51 \\
\hline saliniter $(0 / \ldots)$ & 29.32 & 28.38 & - & 31.67 & 31.21 & 30,18 \\
\hline D. 0 , saturation (z) & 70.7 & 128.3 & - & 83.4 & 160.0 & 250.0 \\
\hline DH & 8.2 & 8.1 & - & 8.1 & 8.3 & 8.7 \\
\hline$N-N H$, (uq et $1^{-1}$ ) & 3.57 & 0.00 & - & 0.70 & 0.70 & - \\
\hline $\mathrm{N}-\mathrm{NO}_{2}$ ( Wg at $-1_{-1}^{-1}$ ) & 1.42 & 2,16 & - & 2.14 & 2.16 & $\cdot$ \\
\hline$N$-No, (ug at: $1^{-1}$ ) & 16.28 & 19.28 & - & 7.86 & 10.00 & - \\
\hline In (tug ot: $\left.1^{-1}\right)$ & 19.27 & 21.42 & - & 10.70 & 12.48 & - \\
\hline popo. (ug at, , $^{-1}$ ) & 1.60 & 2.29 & - & 2.26 & 2.45 & 1.29 \\
\hline$N-N_{0}, ; P-p O$ & 8.9 & 8.4 & - & 3.5 & 4.1 & $\cdot$ \\
\hline \multirow[t]{2}{*}{$H_{g}\left(00.1^{-1}\right)$} & 0.00 & 0.06 & $\cdot$ & 0.15 & 0.25 & 0.00 \\
\hline & Station & 18 llocats & depth: & (2m) & & \\
\hline Tide & high & high & low & high & high & $h l g h$ \\
\hline Sampling time & 13.30 & 13.50 & 13.40 & 15.20 & 13.40 & 14.40 \\
\hline light extinction coef. & 1.90 & 1.00 & 1.70 & 0.90 & 1.20 & 1.20 \\
\hline Water temperature $\left({ }^{\circ} \mathrm{C}\right)$ & 26.70 & 24,70 & 21.20 & 20.34 & 20.37 & 24.39 \\
\hline salinity $(\bullet / .)$. & 18.48 & 30.79 & 22.66 & 28.83 & 29.76 & 32.41 \\
\hline D.0. saturation $(x)$ & 100.0 & 112.3 & 90.0 & 76.3 & 92.8 & 96.7 \\
\hline pH & 7.9 & 8.4 & 7.8 & 8.0 & 8.0 & 8.1 \\
\hline$N-N H$, (ug at, $1^{-1}$ ) & 50.00 & 0.00 & 2.14 & 4.28 & 2.14 & 0.00 \\
\hline$N-\mathrm{NO}_{2}$ ( ng at. $1^{-1}$ ) & 7.85 & 0.70 & 1.42 & 3.57 & 1.42 & 2.73 \\
\hline N-NO, (ug ot, $1^{-1}$ ) & 0.70 & 7.86 & 5.71 & 17.85 & 12.85 & 9.28 \\
\hline IN (ug at. $\left.\left.\right|^{-1}\right)$ & 58.55 & 8.56 & 9.27 & 25.70 & 16.61 & 10.70 \\
\hline p $\rightarrow$ p. (ug at. $\left.\right|^{-1}$ ) & 3.80 & 0.60 & 9.16 & 4.13 & 3.06 & 4.54 \\
\hline $\mathrm{N}-\mathrm{NO}$, : $\mathrm{p}-\mathrm{pO}$ & 0,2 & 13.1 & 0,1 & 4.3 & 4.2 & 2.0 \\
\hline Hg (ug. H $\left.^{-1}\right)$ & 0.00 & 0.85 & 0.55 & 3.64 & 0.10 & 0.00 \\
\hline
\end{tabular}


highest values occurred at Station 18 (3.64 $\mu \mathrm{g} .1^{-1}$ in August), but Station 40, located in the entrance of the Bay, also indicated a concentration of $2.05 \mu \mathrm{g} .1^{-1}$ in June.

The results of the phytoplankton counts at each sampling period are summarized in Table II. In general, highest cel1 concentrations occurred during the warmer months. Four diatom genera, Skeletonema (45\%), Cyclotella (14\%), Leptocylindrus (13\%), and Chaetoceros (11\%) made up about $83 \%$ of the annual total cell number. Diatoms from the genus Skeletonema and phytoflagellate organisms occurred all time and at sampling stations. However, phytoflagellates represented only $4 \%$ of the annual total cell number.

The maximum concentration of Skeletonema was $39.22 \times 10^{6} \mathrm{ce} 11 \mathrm{~s} .1^{-1}$, and was found in December. Phytoflagellate highest concentration $\left(3.37 \times 10^{3}\right.$ cells. $1^{-1}$ ) occurred in February.

Chlorophy11-a concentration ( $\mathrm{Tab}$.

II) was high during summer and relatively low in winter.

The 1ight/photosynthesis curves are shown in Figures 2-4. An inhibition at the maximum energy level could be noted only in samples from Station 24, Apri1, December. On the other hand, the results of five experiments (Station 40, February, April; Station 24, February and Station 18 Februairy and June) indi-

Table 11 - Maximum primary production rates and related factors for the Bay of Santos

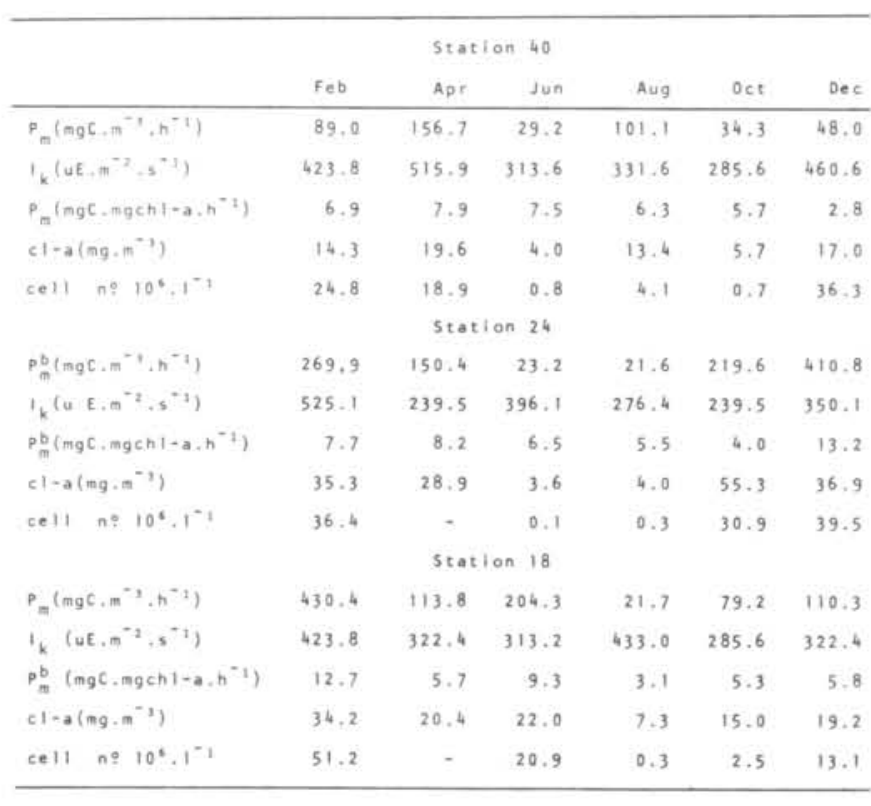

cate that the limiting light level can be over the maximum used.

Maximum production rates were general1y higher during summer ( 34.3 to 488.4 $\left.\mathrm{mgC} \cdot \mathrm{m}^{-3} \cdot \mathrm{h}^{-1}\right)$ than during winter (21.6 to $204.3 \mathrm{mgC} \cdot \mathrm{m}^{-3} \cdot \mathrm{h}^{-1}$ ) (Tab. II). Daily rates varied from 237 to $2.247 \mathrm{mgC} . \mathrm{m}^{-3}$. day $^{-1}$ during winter ( $11 \mathrm{~h}$ of 1 ight) and from 446 to $6.347 \mathrm{mgC} \cdot \mathrm{m}^{-3} \cdot$ day $^{-1}$ during summer

The $I_{k}$ index was graphycally determined according to Talling (1957). The values determined were usually high, (239.5 to $525.1 \mu \mathrm{E} \cdot \mathrm{m}^{-2} \cdot \mathrm{s}^{-1}$ ) but they can be higher yet in the experiments that did not show light saturation.

The photosynthetic indexes $\left(\mathrm{P}_{\mathrm{m}}^{\mathrm{b}}\right)$ (mgC.mg ch1-a.h $\mathrm{h}^{-1}$ ) obtained under the optimum light energy levels are showed in Table II. About $83 \%$ of the samples studied showed $\mathrm{P}_{\mathrm{m}}^{\mathrm{b}}$ values above 5 .

From the time of sampling through the end of the incubation period, samples suffered an increase in the temperatures, averaging $3^{\circ} \mathrm{C}(\mathrm{Tab}$. III). In three cases the experimental temperature had a variation of $5^{\circ} \mathrm{C}$ : Station 40 , December Station 18, August and December, and just the two lower values of $\mathrm{P}_{\mathrm{m}}^{\mathrm{b}}$ were obtained in Station 40, December and Station 18, August, showing a possible adverse influence of an excessive increase of temperature during the experiments.

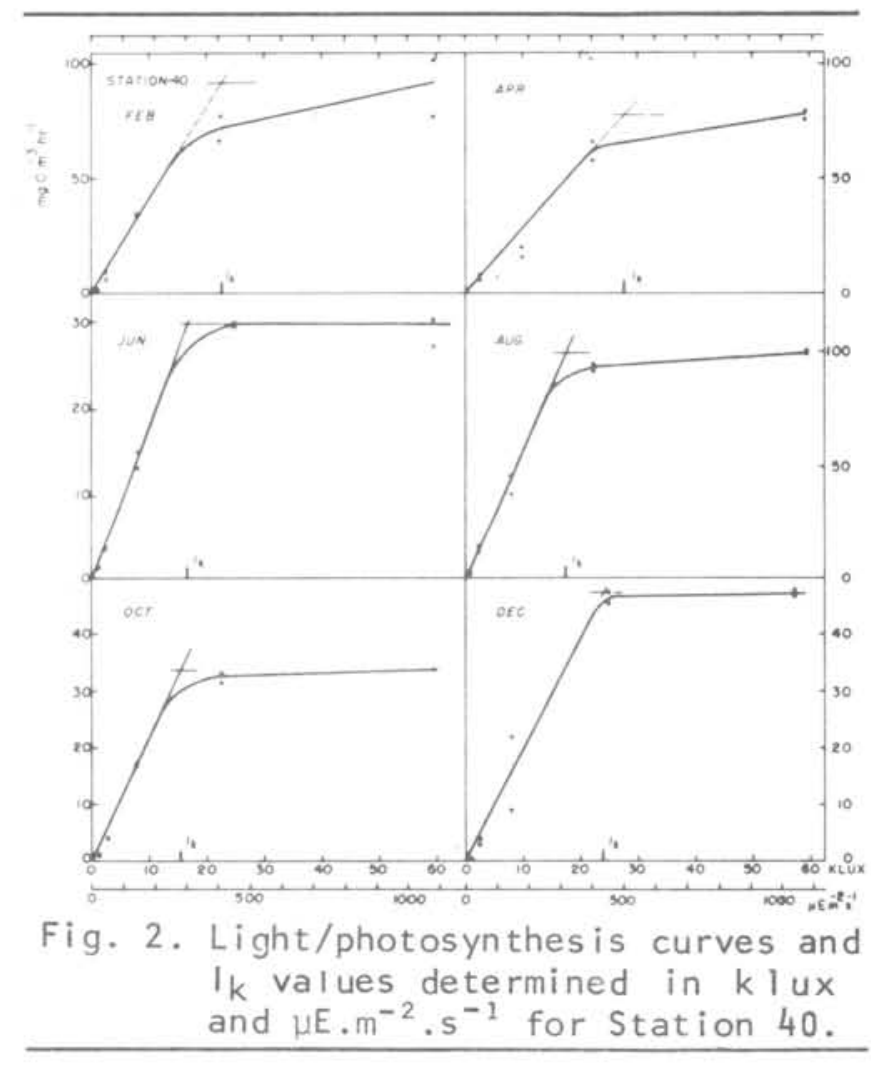




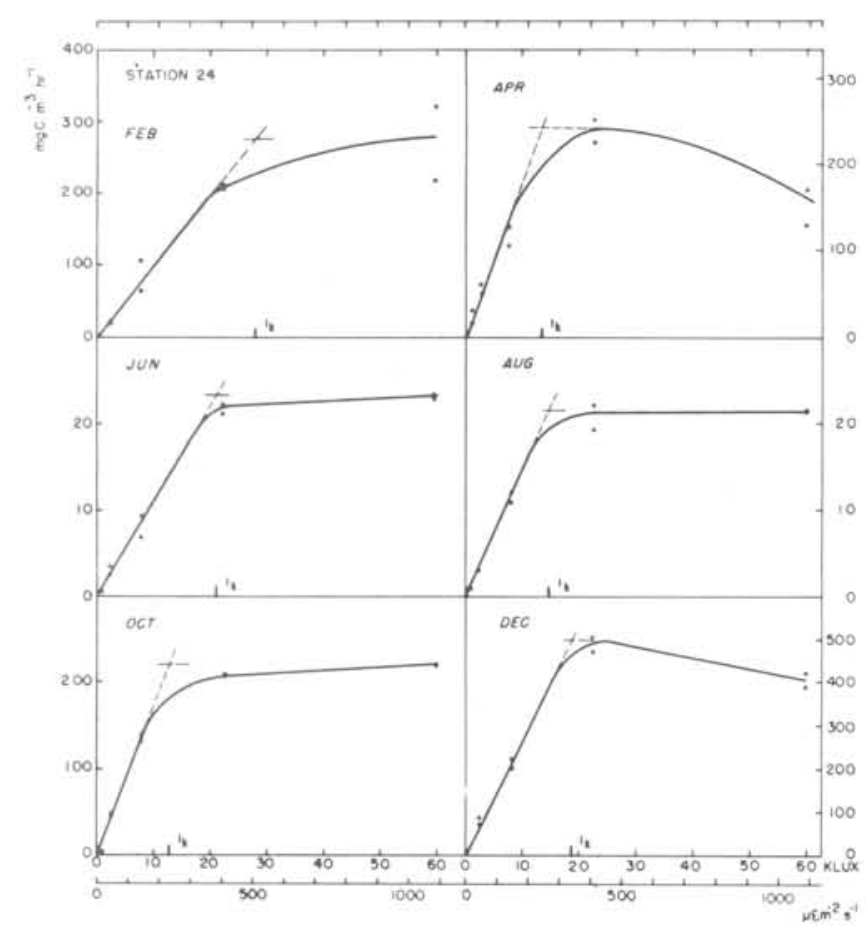

Fig. 3. Light/photosynthesis curves and $I_{k}$ values determined in $k l u x$ and $\mu \mathrm{E} \cdot \mathrm{m}^{-2} \cdot \mathrm{s}^{-1}$ for Station 24 .

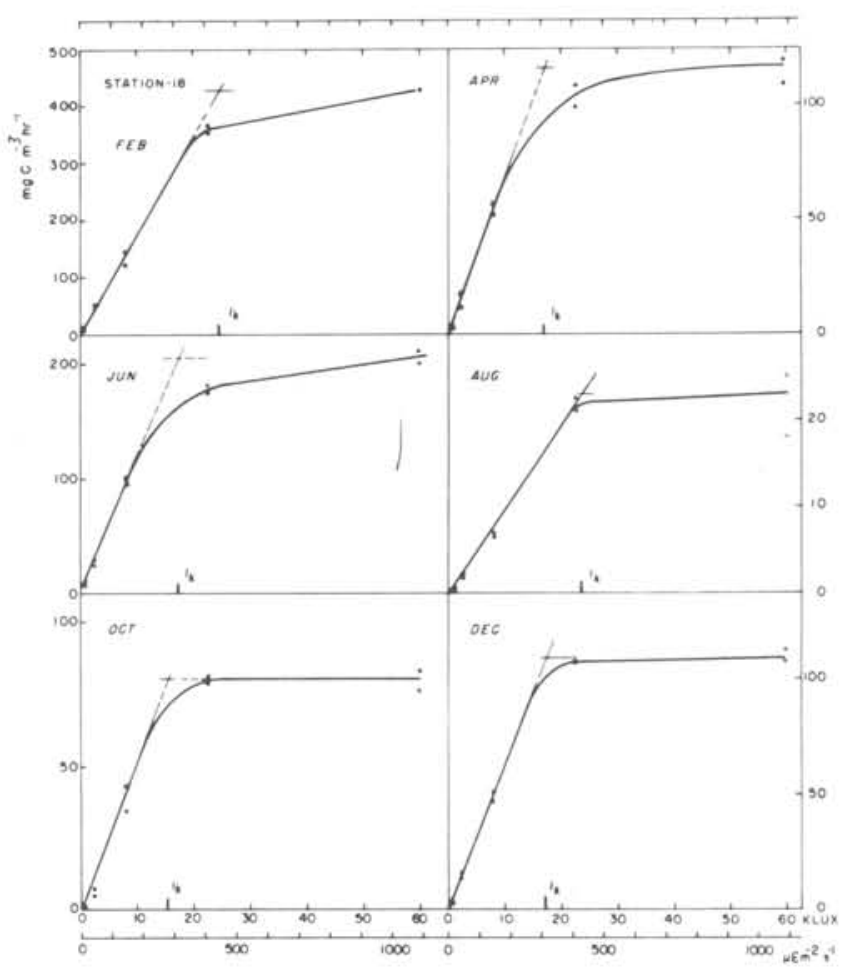

Fig. 4. Light/photosynthesis curves and $I_{k}$ values determined in $k$ lux and $\mu \mathrm{E} \cdot \mathrm{m}^{-2} \cdot \mathrm{s}^{-1}$ for Station 18 .
Table 111 - Experimental temperature data

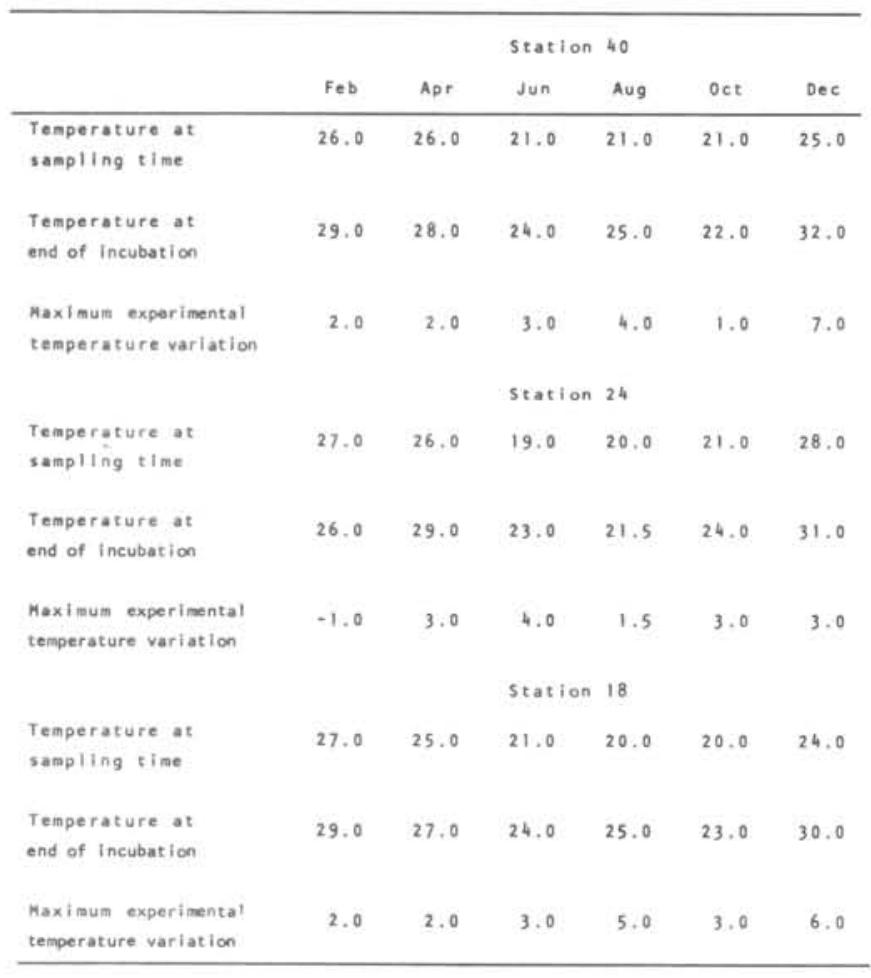

\section{Discussion and conclusions}

The mean annual nutrients gradients recorded agrees with the circulation model suggested by Garcia-Occhipinti (1972). According to this author, during high tide the water affluence occurs through the bottom with an affluence occurring at the surface layer (0-1 m) which circulates from the Estuary out-put, (Station 18) turn round Urubuqueçaba Is1and (near Station 24) and go off the Bay toward SSW (near Station 40); according to Garciaocchipinti (op. cit.), this pattern remains for about $85 \%$ of the time.

A comparison between nutrient data from the Bay of Santos and from other nearby regions (Tab. IV) shows that the region under observation is highly eutrophicated.

Nutrient concentrations from surface coastal waters facing the studied region (Brasil. Ministério da Marinha, 1967) are remarkably lower and confirm the eutrophication of the Bay of Santos.

Caperon et al. (1971) measuring $\mathrm{P}^{-\mathrm{PO}_{4}}$ concentrations at the out-puts of the sewages in Kanehoe Bay, found a mean value of $3.94 \mu \mathrm{gP}-\mathrm{PO}_{4} \cdot 1^{-1}$, which is 
slightly lower than the annual mean value for Station 18 in the Bay of Santos.

In non-polluted waters it is possible to find high nutrient values under upwelling conditions. Wooster \& Cronwell (1958) obtained $2.5-3.0 \mu \mathrm{gP}-\mathrm{PO}_{4} \cdot 1^{-1}$ in Peru coast and Valentin (1974) observed $1.2 \mu \mathrm{gP}-\mathrm{PO}_{4} \cdot 1^{-1}$ in the region of Cabo Frio (RJ). Also nitrogen can be found in relatively high concentrations in upwelling situations, like those determined by Yoneshigue-Braga et al. (1979) in the region of Cabo Frio: 12.58 ugat. $1^{-1}$ of total inorganic nitrogen. In rich waters of the tropical Pacific Ocean, Thomas (1970) recorded $6.33 \mu$ gat $.1^{-1}$ of total inorganic nitrogen. In polluted estuaries these values can rise up to $43.0 \mu$ gat. $1^{-1}$ of $\mathrm{N}-\mathrm{NO}_{3}$, like those determined by Berland et al. (1973) at the estuary out-fall of the Grand Rhone.

Teixeira \& Gianesella-Galvão (in preparation), working on bioassays with waters from the Bay of Santos demonstrate that populations of Phaeodactylum tricornutum can be mantained at very high densities (about $40.10^{6}$ cell. $1^{-1}$ ).

The low $\mathrm{N}: \mathrm{P}$ ratios found in the present work are due to high phosphate concentrations and not to low nitrogen concentrations.

The annual fluctuations of the phytoplankton standing-stock, with higher values in summer and lower in winter are typical for coastal regions at nearby latitudes (Teixeira, 1969; 1980) due to the maxima of solar radiation and precipitation that occur in summer. However, at this time of the year there is a sharp increasing in the organic pollution of domestic origin in the Bay of Santos, due to the increasing of population in Santos and São Vicente towns. This fact, with no doubt, causes a preponderant fertilizing effect in the

Table IV - Nutrient data from the Bay of Santos and other nearby regions

\begin{tabular}{|c|c|c|c|}
\hline Reglan & $\begin{array}{l}\text { Mitrate } \\
(\text { ugn. }\end{array}$ & $\begin{array}{l}\text { Phosphate } \\
\left(\mu g p=1^{-1}\right)\end{array}$ & Author \\
\hline Cananäle (estuary) & $<0.1-3.0$ & $<0.1-0.7$ & Kato, 1966 \\
\hline Ubetube (bey) & $0.06-0.60$ & $0.01-0.25$ & Telxeira, 1980 \\
\hline Santos (cosstel waters) & $0.3-0.50$ & 0.1 & $\begin{array}{l}\text { Orassli, Ninistério } \\
\text { da Marinha, } 1967\end{array}$ \\
\hline Santos (bay) & $0.00-19.28$ & $0.19-9.16$ & This study \\
\hline
\end{tabular}

Bay of Santos waters.

The standing-stock data found during the summer were high even compared with those from other eutrophic regions. In Cananéia, Kutner (1972) found about $19.10^{6}$ cel1. $1^{-1}$ in summer, during the standing-stock peak. In Santos, the highest value was $51.2 \times 10^{6}$ cell. $1^{-1}$.

Benon et al. (1977) observed in the Golfe de Marseille (polluted), phytoplankton populations higher than $10^{6}$ ce $11.1^{-1}$. In that region, Skeletonema costatum always dominated in the phytoplankton (up to $99 \%$ of the total phytoplankton). Blanc et al. (1975) studying the Golfe de Fos also found $S$. costatum populations representing about $95 \%$ of total phytoplankton that reached up to $73.10^{6}$ cells. $1^{-1}$. Kutner (op. cit.) observed S. costatum attaining $88 \%$ of the total phytoplankton in the region of Cananéia. In Santos, Skeletonema reached up to $99 \%$ during the summer.

Chlorophy11- $a$ concentrations were rather high and McCormich \& Quinn (1975) obtained similar values $(3.0-81.0$ mgch $1-a \cdot \mathrm{m}^{-3}$ ) in a polluted estuary (Newark Bay, New Jersey). In spite of the climatic differences, both regions present similar pollution problems (domestic wastes, petrochemical plants, harbours). Teixeira (pers. comm.)* observed chlorophy11- $a$ concentrations around $100 \mathrm{mg} \cdot \mathrm{m}^{-3}$ in the Bay of Santos.

The phytoplankton primary production rates were very high, higher than those obtained for other tropical estuaries and bays (Table V). However, mercury concentrations may be affecting the production rates: highest mercury values observed (Station 40, June and Station 18, August) occurred concomitantly with lowest production rates. High mercury concentrations affect some algae species significantly, and Skeletonema costatum is one of the more sensitive (Overne11, 1976).

The $I_{k}$ values were also very high. Harris (1978) looking over published data verified that most of the values recorded fall within the range of 50$120 \mu \mathrm{E} \cdot \mathrm{m}^{-2} \cdot \mathrm{s}^{-1}$ of the photosynthetic active radiation. However the present experiment was done under simulated conditions, and consequently our data are not comparable to those obtained by

* Teixeira, C. - Inst. oceanogr. da USP, 1976. 
Bolm Inst. oceanogr., S Paulo, 31(2), 1982

Harris (op. cit.). Teixeira (1980), working with natural phytoplankton populations from Ubatuba region, made incubation experiments similar to that of the present study (incandescent light, maximum of $831.1 \mu \mathrm{E} \cdot \mathrm{m}^{-2} \cdot \mathrm{s}^{-1}$ ) and also obtained very high $\mathrm{I}_{\mathrm{k}}$ values: 460.6 to

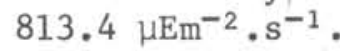

High $I_{k}$ values indicate that the phytoplankton from the Bay of Santos presents a "sun pattern" behaviour. This phenomenon is likely to be due to the high temperature of the water throughout the year and to the thermohaline stratification of the Bay.

The effect of the temperature over the light adaptation speed has been verified in recent works. Hitchcock (1980) working with cultures of Skeletonema costatum growing under temperatures of 2,10 and $25^{\circ} \mathrm{C}$, verified that the maximum adaptation speed was obtained at the latter, more similar to the surface temperature from the studied region. This effect is due to the thermal dependence of the enzimatic activities of photosynthesis. Malone \& Neale (1981) working with $I_{k}$ index also emphasize the temperature effect over it.

The thermohaline isolation of the surface layer in region, could allow the phytoplankton to remain there and adapt to high light radiations. A rapid adaptation to new light conditions was verified by Marra (1978) who concluded that the changes in the photosynthetic capability depend mainly on the time of exposure at each radiation level.

Vincent (1980) also verified the fastness of photosynthetic adaptation in natural assemblages by changes in the photosynthetic capability. In this case, the adaptation process seems to have occurred with time intervals shorter than a generation. Therefore, the proposed mechanism of adaptation might be sufficient to explain the absence of superficial inhibition phenomena observed at the production profiles in the present work.

Gianesella-Galvão (1981) studying the primary production and temperature profiles in reservoirs of São Paulo State (approximately the same latitudes as those of the Bay of Santos) observed a high percentage of production profiles with surface maxima during thermal isolation of the surface layer during the diurnal heating. Due to this adaptation ability and the favourable nutritional conditions, it could be expected that a high $\mathrm{p}_{\mathrm{m}}^{\mathrm{b}}$ would occur during summer.

An excessive increase in temperature during incubation probably affected the cell metabolism and accounted for some of the low $\mathrm{P}_{\mathrm{m}}^{\mathrm{b}}$ values obtained in December (Stations 40 and 18). Also the relatively low $\mathrm{Pb}$ value obtained in August (Station 24) may have resulted from the same technical problem.

Recently, the $\mathrm{P}_{\mathrm{m}}^{\mathrm{b}}$ index has been carefully studied by several authors (Gargas et al., 1979; Teixeira, 1980) who have emphasized the influence of diel variations on this parameter, besides those effects due to temperature (Eppley et al.,1972; Malone \& Neale, 1981), nutritional conditions (Glooschenko \& Cur1 Jr., 1971; Thomas, 1980), light regime (Vincent, 1980; Marra, 1978) and species composition (Parsons et al., 1977).

As field work does not always allow a high accuracy level, this index has been used for comparing productivity aspects of several regions of the world in spite of being problematic. The standardization of the light conditions, however, permits more comparable results on the primary production potential of the region than those obtained by "in situ" simulated experiments.

Holmes (1958) doing "in situ" experiments with natural populations of phytoplankton from the tropical Pacific obtained values higher than those from simulated experiments at $10 \mathrm{Klux}$. In the present work the illumination level was higher ( $60 \mathrm{~K} 1 \mathrm{ux}$ ) and quantitatively closer to natural conditions. But even so, since incandescent light does not reproduce integrally the solar spectrum, the photosynthetic structure might not have been fully utilized and the $\mathrm{P}_{\mathrm{m}}^{\mathrm{b}}$ can be subestimated again.

Although there seems to be a possibility of the $\mathrm{P}_{\mathrm{m}}^{\mathrm{b}}$ values having been underestimated, as discussed, previously, the results obtained in the Bay of Santos are comparable to those of other eutrophic environments ( $\mathrm{T} a \mathrm{~b} . \mathrm{V})$, and are generally included in the range suggested by Cur1 Jr. \& Small (1965) as typical for eutrophic waters. 
Table V - Primary production (mgC. $\left.\mathrm{m}^{-3} \cdot \mathrm{hr}^{-1}\right)$ and $\mathrm{P}_{\mathrm{m}}^{\mathrm{b}}$ indexes $\left(\mathrm{mgC} \cdot \mathrm{mgchl}^{-1} \cdot \mathrm{h}^{-1}\right)$ at several tropical marine environments

\begin{tabular}{|c|c|c|c|c|c|}
\hline Region & Incubation & Hlumination & $\begin{array}{l}\text { Primary } \\
\text { production* } \\
\left(\mathrm{mgC} \cdot \mathrm{m}^{-3} \cdot \mathrm{h}^{-1}\right)\end{array}$ & $\begin{array}{l}P_{m}^{b} \text { indexes } \\
\left.(m g C \cdot m g c h)_{a}^{-1} \cdot h^{-1}\right)\end{array}$ & Authors \\
\hline \multicolumn{6}{|l|}{ Breton Sound } \\
\hline $29^{\circ} 30^{\prime} \mathrm{N} ; 89^{\circ} 20^{\prime} \mathrm{W}$ & "in situ" or & & $0.7-221.0$ & & \\
\hline $\begin{array}{l}81 \text { lind Bay } \\
29^{\circ} 10^{\prime} N ; 89^{\circ} 00^{\prime} W\end{array}$ & $\begin{array}{l}\text { "in situ" } \\
\text { simulated }\end{array}$ & natural & $2.6-189.0$ & - & Thomas a Simmons (1960) \\
\hline $\begin{array}{l}\text { Kaneohe Bay } \\
21^{\circ} 27^{\prime} \mathrm{N} ; 157^{\circ} 47^{\prime} \mathrm{W}\end{array}$ & simulated & artificial & $5.0-10.0$ & $6.15-7.94$ & Doty \& Capurro (1961) \\
\hline I dem & $\begin{array}{l}\text { "in situ" } \\
\text { simulated }\end{array}$ & natural & $4.8-37.9$ & $7.15-14.54$ & Caperon et al. (1971) \\
\hline $\begin{array}{l}\text { Ala Way Canal } \\
21^{\circ} 15^{\prime} \mathrm{N} ; 157^{\circ} 50^{\circ} \mathrm{W}\end{array}$ & "in situ" & natural & $\begin{array}{c}231.0 \\
\text { (annual average) }\end{array}$ & $12.22-16.31$ & Harris (1975) \\
\hline $\begin{array}{ll}\text { Cananeita } B r & (S P) \\
25^{\circ} 04^{\prime} S: & 47^{\circ} 54^{\prime} W\end{array}$ & simulated & $57 \mathrm{Klux}$ & $\begin{array}{l}65.32-206.12^{\star \star *} \\
54.37-117.37 * \star *\end{array}$ & $11.80-24.00$ & Telxeira (1969) \\
\hline I dem & simulated & $16 \mathrm{klux}$ & $9.86-70.59$ & $3.28-6.25$ & Tundisi (1969) \\
\hline I dem & "in situ" & natural & $3.00-72.00$ & $0.27-21.18$ & Tundist et al. (1973) \\
\hline $\begin{array}{l}\text { Ubatuba Br (SP) } \\
23^{\circ} 30^{\prime} S ; 45^{\circ} 06^{\prime} W\end{array}$ & "in situ" & natural & $\begin{array}{l}1.01-28.16 \text { k* } \\
0.24-16.24 * \star *\end{array}$ & $5.08-9.65$ & Teixeira (1973) \\
\hline Idem & simulated & $=45 \mathrm{klux}$ & - & $1.36-6.80$ & Teixeira (1980) \\
\hline $\begin{array}{l}\text { Bay of Santos Br (SP) } \\
24^{\circ} 00^{\prime} \mathrm{S}: 46^{\circ} 26^{\prime} \mathrm{H}\end{array}$ & simulated & $60 \mathrm{klux}$ & $\begin{array}{l}34 \cdot 3-488 \cdot 4 \pi \star \\
21.6-204.3^{\star \star \star \star}\end{array}$ & $2.81-13.2$ & This study \\
\hline$\star 10 \mathrm{c}$ method & & & & & \\
\hline $\begin{array}{ll}* * & \text { Summer } \\
* * * & \text { Winter }\end{array}$ & & & & & \\
\hline
\end{tabular}

\section{Acknowledgements}

This study was conducted as a partial fulfillment for a master dissertation degree and supported by the National Council for Scientific and Technological Development. I would like to thank Dr. C. Teixeira for his guidance in the experimental work and for the valuable discussions. Furthermore, I thank the Instituto Oceanográfico da Universidade de São Paulo and Companhia de Tecnologia de Saneamento Ambiental for providing funds and facilities for this work.

\section{References}

A.P.H.A. (American Public Health Association). 1971. Standard methods for the examination of water and wastewaters, including bottom sediments and sludges. $13^{\text {rd }}$ ed. New York, Am. Public Health Ass., AWA-WPCF, 874p.

BENON, P.; BOURGADE, B. \& KANTIN, R. 1977. Impact de la pollution sur les écosystemes mëditerranéens côtiers - Aspects planctoniques. Thése docteur de 3 éme cycle. Marseille, Centre Universitaire de Marseille-Luminy, 2v.

BERLAND, B. R.; BONIN, D. J.; MAESTRINI, S. Y. \& POINTIER, J. P. 1973. Etude de 1a fertilité des eaux marine au moyen de tests biologiques effectués avec des cultures d'algues. IV-Etude d'eaux côtiēres méditerraneénnes. Int. Revue ges. Hydrobio1., 58(4):473-500.

BLANC, F.; LEVEAU, M. \& BONIN, M. C. 1975. Ecosysteme planctonique. Structure et fonctionnement en relation avec des phénomènes de dystrophie (Golfe de Fos). Int. Revue ges. Hydrobiol., 60(3):359-378.

BRASIL. MINISTERIO DA MARINHA. 1967. XXXIII Comissão oceanogrāfica N/Oc. "Almirante Saldanha" (14/03 a 03/05/1967). DHN, série D.G. 26-X. 
BRAY, G. A. 1960. A simple efficient liquid scintillator for counting aqueous solutions in a liquid scintillation counter. Analyt. Biochem., $1: 279-285$.

CAPERON, J.; CATTELL, S. A. \& KRASNICK, G. 1971. Phytoplankton kinetics in a subtropical estuary: eutrophication. Limnol. Oceanogr., 16(4):599-607.

CURL Jr., H. \& SMALL, L. F. 1965. Variations in photosynthetic assimilation ratios in natural marine phytoplankton communities. Limnol. Oceanogr., 10 (supp1.):67-73.

DOTY, M. S. \& CAPURRO, L. R. A. 1961. Productivity measurements in the world ocean. Part 1. IGY Oceanogr. Rep., (4) : 1-298.

EPPLEY, R. W.; CARLUCCI, A. F.; HOLMHANSEN, 0.; KIEFER, D. A.; MCCARTHY, J. J. \& WILLIAMS, P. M. 1972. Evidence for eutrophication in the sea near Southern California coastal sewage outfalls, July, 1970. CalCOFI Rep., Calif. Mar. Res. Commn, 16:74-83.

FITZGERALD, W. F. \& LIONS, W. B. 1973. Organic mercury compounds in coastal waters. Nature, Lond., 242 (5398) : 452-453.

GARCIA-OCCHIPINTI, A. 1972. Estudos para o sistema de disposição oceânica de esgotos de Santos e São Vicente. Revta DAE, (86):155-176.

\& TEIXEIRA, C. 1961. Diurnal variation of phytoplankton production and solar radiation in coastal waters off Cananéia. Bolm Inst. oceanogr., S Paulo, 11(3):17-40.

GARGAS, E. 1975. A manual for phytoplankton primary production studies in Baltic. Publ. Balt. mar. biologists, Dan. Ag. Environ. Prot., (2):1-88.

; HARE, I.; MARTENS, P. \& EDLER, L. 1979. Diel changes in phytoplankton photosynthetic efficiency in brackish waters. Mar. Biol., 52:113-122.
GIANESELLA-GALVÃO, S. M. F. 1981. Produção primāria e suas relações com alguns fatores físico-químicos em reservatórios do Estado de São Paulo. Tese de Doutorado. Universidade de São Paulo, Instituto Oceanogräfico, 2 v.

GLOOSCHENKO, W. A. \& CURL Jr., H. 1971. Influence of nutrient enrichment on photosynthesis and assimilation ratios in natural North Pacific phytoplankton communities. J. Fish. Res. Bd Can., 28(5):790-793.

HARRIS, C. L. 1975. Primary production in the Ala Way Canal, a small tropical estuary. Hawaii Inst. of Geophysis. HIG-75-7:1-34.

\section{productivity and growth: the physiological ecology of phyto- plankton. Arch. Hydrobiol. Beith. Ergebn. Limno1., 10(1/4):1-171.}

HITCHCOCK, G. L. 1980. Diel variation in chlorophyll-a, carbohydrate and protein content of the marine diatom Skeletonema costatum. Mar. Biol., 57:271-278.

HOLMES, R. W. 1958. Size fractionation of photosynthesizing phytoplankton. Spec. scient. Rep. U.S. Fish. Wild. Serv. Fisheries, 279:69-71.

KATO, K. 1966. Chemical investigations on the hydrographical system of Cananéia lagoon. Bolm Inst. oceanogr., S Paulo, 15(1):1-12.

KUTNER, M. B. B. 1972. Variação estacional e distribuição do fitoplâncton na região de Cananéia. Tese de Doutorado. Universidade de São Paulo, Instituto Oceanogräfico, 104p.

MALONE, T. C. \& NEALE, P. J. 1981. Parameters of 1ight-dependent photosynthesis for phytoplankton size fractions in temperate estuarine and coastal environment. Mar. Biol., $61: 289-297$.

MARRA, J. 1978. Phytoplankton photosynthetic response to vertical movement in a mixed layer. Mar. Biol., 46:203-208. 
MCCORMICK, J. \& QUINN, P. I. 1975. Phytoplankton diversity and chlorophy11-a in a polluted estuary. Mar. Pollut. Bu11., 6(7):105-106.

OVERNELL, J. 1976. Inhibition of marine algal photosynthesis by heavy metals. Mar. Biol., 38(4): 335-342.

PARSONS, T. R.; TAKAHASHI, M. \& HARGRAVE, B. 1977. Biological oceanographic processes. Oxford, Pergamon Press, $332 \mathrm{p}$.

STEEMANN-NIELSEN, E. 1952. The use of radioactive carbon $\left({ }^{14} \mathrm{C}\right)$ for measuring organic production in the sea. $\mathrm{J}$. Cons. perm. int. Explor. Mer, 18:117140 .

STRICKLAND, J. D. H. \& PARSONS, T. R. 1968. A practical handbook of sea water analysis. Bul1. Fish. Res. Bd Can., (167): 1-311.

TALLING, J. F. 1957. Photosynthetic characteristics of some fresh water plankton diatoms in relation to under-water radiation. New Phytol., $56: 29-50$.

TEIXEIRA, C. 1969. Estudo sôbre algumas caracterîsticas do fitoplâncton da região de Cananéia e o seu potencial fotossintético. Tese de Doutorado. Universidade de São Paulo, Fac. Filos. Ciēnc. Letr., 82 p.

1973. Preliminary studies of primary production in the Ubatuba region. Bolm Inst. oceanogr., S Paulo, 22:49-58.

1980. Estudo quantitativo da produção primāria, clorofila-a e parâmetros abiōticos em relação à variação temporal (Lat $23^{\circ} 30^{\prime} \mathrm{S}$ - Long. $\left.45^{\circ} 06^{\prime} \mathrm{W}\right)$. Tese de Livre-Docência. Universidade de São Paulo, Instituto Oceanogrāfico, 243 p.

\section{; TUNDISI, J. G. \& SANTORO-}

YCAZA, J. 1969. Plankton studies in a mangrove environment. VI-Primary production, zooplankton standingstock and some environmental factors. Int. Revue ges. Hydrobiol., 54 (2): 289-301.
THOMAS, W. H. 1970. On nitrogen deficiency in tropical Pacific oceanic phytoplankton: photosynthetic parameters in poor and rich waters. Limnol. Oceanogr., 15:380-385.

\section{\& SIMMONS, E. G. 1960.}

Phytoplankt on production in Mississippi Delta. In: Sheppard, F. P.; Phleger, F. B. \& Van Ade1, T. J., eds. Recent sediments: Northwest Gulf of Mexico. Tulsa, Oklahoma, Am. Ass. Petrol. Geologists, p. 103-116.

TUNDISI, J. G. 1969. Produção primāria, "standing-stock" e fracionamento do fitoplâncton na região lagunar de Cananéia. Tese de Doutorado. Universidade de São Paulo, Fac. Filos. Ciênc. Letr., 130 p.

, TUNDISI, T. M. \& KUTNER, M. B. B. 1973. Plankton studies in a mangrove environment. VIII-Further investigations on primary production, standing-stock of phyto and zooplankton and some environmental factors. Int. Revue ges. Hydrobiol., 58(6):925-940.

UTERMŐHL, H. 1958. Zur Vervolkommnung der quantitativen phytoplanktonmethodik. Mitt. Int. Verein. Limno1., 9:1-38.

VALENTIN, J. 1974. O plâncton na ressurgência de Cabo Frio (Brasi1). II Primeiras observações sobre a estrutura física, química e biológica das āguas da estação fixa. (Período de 04/02 a 16/04/1973). Publções Inst. Pesq. Mar., (083):1-11.

VINCENT, W. F. 1980. Mechanisms of rapid photosynthetic adaptation in natural phytoplankton communities. II-Changes in photochemical capacity as measured by DCMU - induced chlorophy11 fluorescence. J. Phycol., $16: 568-577$.

WARD, F. J. \& NAKANISHI, M. 1971. A comparison of Geiger-Mueller and liquid scintillation counting methods in estimating primary productivity. Limno1. Oceanogr., 16:560-563.

WOOSTER, W. S. \& CRONWELL, T. 1958. An oceanographic description of the eastern tropical Pacific. Bull. Scripps. Inst. Oceanogr., 7(3):169-282. 
YONESHIGUE-BRAGA, Y.; MAESTRINI, S. Y. \& GONZALEZ-RODRIGUEZ, E. 1979.

Fertilité et facteurs nutritionnels limitant 1a croissance des producteurs primaires des eaux de 1'"upwelling" de Cabo Frio (Brésil). Etude preliminaire. C. R. Acad. Sc. Paris, t 288, série D-135.

(Manuscript received on 15/June/1982; accepted on $01 /$ Dec./1982) 